\title{
Developing of Flat Building Media in Using Macromedia Flash Postgraduate Program of Medan State University
}

\author{
Erningsih, Dian Armanto, Anita Yus \\ Medan State University \\ Medan, Indonesia \\ Unimed.ac.id
}

\begin{abstract}
This research were motivated by 1) the importance of the media in delivering learning material to make it more interesting; (2) there was no learning media on flat building material by developing Macromedia Flash Professional applications in the form of CD (Compact Disk); (3) Student learning outcomes were still low and had not yet reached the KKM, (4) SDN 104258 PematangBiara had complete learning facilities but it was not utilized; (5) Students often find it difficult to learn mathematics; (6) difficulty in flatbuilding material; (7) The media used was not varied so that it caused boredom in students. The goal that should been achieved in the effort to develop this learning media was to produce valid, practical and effective mathematics teaching materials. This type of research was research and development. The development model used was referring to Research and Development ( $R$ \& D) from the Borg and Gall model. The research data from the validity test was obtained through the validation material for teaching materials. Practical data was collected through the response of teachers and students. Effectiveness could be seen from student learning outcomes through pretest and posttest scores. The collected data were analyzed descriptively. The results of the validity test showed that the resulting mathematics teaching material was valid. The results of observations and questionnaires stated that this learning tool was practical. At the effectiveness test stage, the Paired Sample $\mathbf{T}$ Test results obtained that the $\mathbf{T}$ count value was -5.311 when compared with the Ttable value of $\mathbf{- 2 . 0 2 8}$ thus it could be seen that $T$ count $>T$ table could be interpreted that the average value of students' mathematics learning outcomes was higher after using Macromedia media Flash (Postes) was compared before using Macromedia Flash (Prestes) media. Based on these results, it could be concluded that the learning media was flat building with using macromedia flash for the fourth grade students of SDN 104258 PematanBiara which has been produced can be declared valid, practical, and effective.

Keywords: learning media, macromedia flash
\end{abstract}

\section{INTRODUCTION}

Technological development and capabilities are very related to the ability of science. Related to these developments, mathematics as a science has many roles. Russefendi (sudjana, 2002: 1) argues, "Mathematics is important as a form of attitude, therefore one of the tasks of the teacher is to encourage students to learn very well". ". Dewey (in Ibrahim, et al. 2002: 76) suggests that learning is what the students must do by themselves, and then learning initiatives must emerge from themselves. Here the teacher's task is to provide learning material but the process and comprehension are the students according to their respective talents, abilities, and backgrounds. But, the reality in the field, the process of teaching and learning activities in the classroom, the learning of exact subjects, especially Mathematics, the response was not good. As stated by Effendi (in slameto, 2003: 2) that mathematics (exact science) for children are generally a subject that is not enjoyed or it is a lesson that is hated. This research was motivated by 1) the importance of the media in delivering learning material to be more interesting; (2) there was no learning media on flat building material by developing Macromedia Flash Professional applications in the form of CD (Compact Disk)(3) Student learning outcomes were still low and had not yet reached the KKM, (4) SDN (primary school) 104258 PematangBiara had completed with learning facilities but was not utilized; (5) Students often find it difficult to learn mathematics; (6) difficulty in building flat material; (7) The media used was not varied so that it caused boredom in students. The goal that should be achieved in the effort to develop this learning media is to produce valid, practical and effective mathematics teaching materials..

\section{RESEARCH METHODS}

In this research and development, the model developed referred to Research and Development (R \& D) from Borg and Gall's (1983) model. In the development model, Borg and Gall contained a systematic guide to the steps taken by researchers so that the product they have designed has a feasibility standard.

The reviewer and product testing stage were carried out by material experts, instructional media experts, and graphic design experts. After going through the revision stage, it was continued to students with three stages, namely individual 
trials, small group trials, and field trials so that the appropriate learning media were produced in accordance with the characteristics of the field of study and student users. Through a series of trials to students, finally, the final product of learning media was produced by including suggestions and revisions from material experts, media experts, and design experts, as well as students. The development procedures taken to produce Macromedia Flash-based learning products were divided into 11 (eleven) stages according to Ketang (2012), namely: (1) the first stage of conducting preliminary research, this stage was began with identification of learning needs and determining competency standards of subjects, conducting analysis learning, identifying the characteristics and initial behavior of students, determining basic competencies and indicators, writing benchmark reference tests, developing learning materials, (2) the second stage of media design making. The second stage begins with the making of software design, script writing, storyboard making, flowchart making, (3) the third stage of material collection, beginning with the collection of materials for making and collecting animation, recording and collecting audio, (4) the fourth stage of developing forms the beginning of Macromedia Flash Based Learning Media products, which were completed with media instructions such as: learning instructions, brief descriptions, basic competencies, description of material, practice questions, the last as a conclusion was a summary, and (5) the fifth stage was doing validation products from media experts, material experts and design experts, (6) the sixth stage, revising the first stage of the results from the experts' validation, (7) the seventh stage, revising of the beginning stage of the product, (8) the eighth stage, conducting one by one with prospective students using multimedia interactive learning, (9) the ninth stage was doing the second stage revision, (10) the tenth stage was doing field trials, (11) the eleventh stage, namely, doing the final revision developed in the form of Macromedia Flash professional learning media.

\section{DISCUSSION}

The assessment results of the three experts on the learning media developed were as followed:

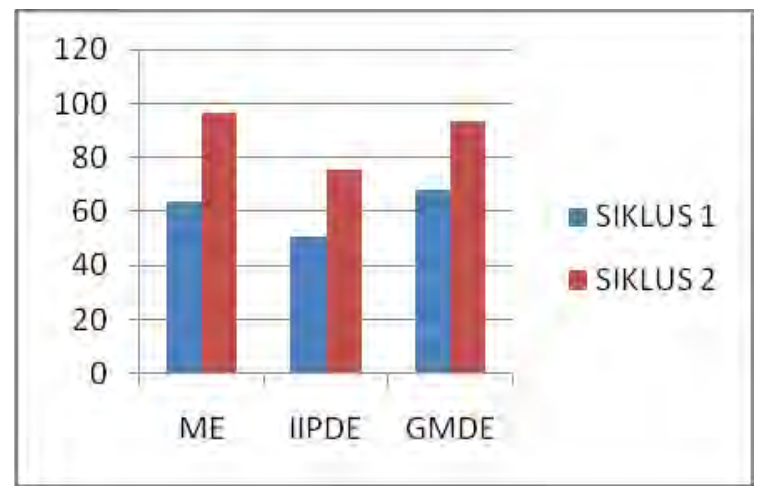

Fig 1. graph expert validation
ME :Material Expert

IIPDE :Information Interaction and Presentation Design Expert

GMDE :Graphic and Media Design Expert

It could be seen from the graph that expert validation that has been assessed by each expert was categorized very well, loaded with $96.45 \%$ material experts, information, interaction and presentation design experts, $75.44 \%$ and graphics and media design experts $93.33 \%$. From the results of the validation, the developed learning media could be declared valid and could be applied to students. This was also reinforced by the advice of experts that the media was suitable for use.

\section{CONCLUSIONS}

Based on the results of the research, development, and discussion previously stated, it could be concluded:

1. Learning media based on Macromedia Flash Professional that was used in Mathematics subjects with developedflat building material wasvalid, practical and effective.

2. Learning media based on Macromedia Flash Professional was more feasible than learning media for textbooks (notes) to be used in Mathematics learning with flat building material for Class IV SD Negeri 104258 Pematang Biara which could be disseminated and implemented to users.

3. Mathematics learning outcomes that were taught with Macromedia Flash Professional-based learning media were higher than learning outcomes taught by learning textbooks (notes) on flat building material for Grade IV students of SD Negeri 104258 Pematang Biara.

\section{SugGestion}

Based on the conclusions and implications as stated, the following were suggested:

1. It was expected that teachers who teach in class should have the willingness to make learning media that did not yet exist or develop existing learning media to overcome limitations in the delivery of information in the learning process.

2. This interactive learning media should be used by teachers as one of the effective media and could increase student learning interest.

3. Researchers were expected to continue their research on the design and development of learning media.

\section{REFERENCES}

[1] Sudjana, Nana. . Dasar-Dasar proses Belajar Mengajar. Bandung: Sinar Baru Algesindo. 2002

[2] Slameto. 1995. Belajar dan Faktor-faktor yang Mempengaruhinya. Jakarata: Rineka Cipta. 
[3] Arsyad, Azhar. 1997. Media Pengajaran. Jakarta: Raja Grafindo Persada

[4] Dahar, R. W. 1989. Teori-Teori Belajar. Jakarta: Erlangga

[5] Bruner, J. S. The Process of Education. New York: Vintage Book. 1960
[6] Arief S Sadiman dkk. Media Pendidikan: Pengertian, pengembangan, dan pemanfaatannya. Jakarta: RajaGrafindo Persada.

2006 